\title{
Charles BurnetT
}

European knowledge of Arabic texts referring to music: some new material

OWEN ReEs

Guerrero L'homme armé masses and their models

Kay Kaufman Shelemay, Peter Jeffrey and Ingrid Monson

Oral and written transmission in Ethiopian Ghristian chant

ANDREW WATHEY

The motets of Philippe de Vitry and the fourteenth-century renaissance

EVELYN S. WELCH

Sight, sound and ceremony in the chapel of Galeazzo Maria Sforza

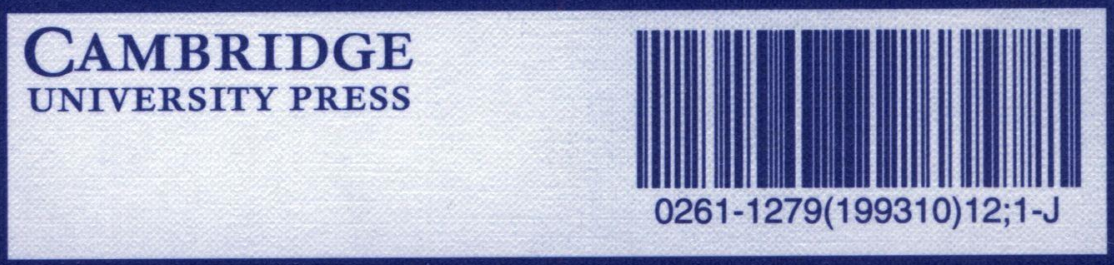

